\title{
College students' problems and their link to academic performance: Basis for needs- driven student programs
}

\author{
Januard D. Dagdag, Hydee G. Cuizon and Aisie O. Bete \\ Isabela State University, Philippines \\ Corresponding author: januard.d.dagdag@isu.edu.ph
}

DOI: https://doi.org/10.37134/jrpptte.vo19.no2.5.2019

Received: 14 April 2019; Accepted: 5 November 2019; Published: 5 December 2019

\begin{abstract}
Students are facing various challenges in life that may have adverse effects to their academic performance yet some school programs are not student needs-driven. This descriptive research study discusses the problems experienced by the 350 students of a higher education institution in the Philippines with the hope to craft activities that are responsive to their needs and academic achievement. The data were collected through questionnaire and registration methods. Descriptive analysis shows that around 9 percent to 23 percent of the students experience problems in academic, social, family, emotional, personal, financial and spiritual aspects whose degree ranges from moderate extent to very great extent. The problems reflect teachers' lapses in classroom management and pedagogy, and lack of activities that support students' holistic development and effective learning habits. Linear regression analysis confirms that their problems explain significantly a variance that ranges from 19 percent to 36 percent in their academic performance. Hence, this research offers implications that can help address the adversaries of high academic achievement.
\end{abstract}

Keywords: Academic performance, college students, needs-driven, student programs,

\section{INTRODUCTION}

Historically, education has been focusing more on the program needs than on students' needs (Mayes \& McConatha, 1982). Students' needs are ignored hence the services delivered by schools are not often accurate and effective (Mayes \& McConatha, 1982). School systems are not responsible for meeting all these needs, however, when these directly affect learning, schools must meet the challenges as the goal of teaching is attained only when they have addressed these needs that interfere with their students' learning (Ramsey, 2000).

The implementation and adoption of Outcomes-based Education (OBE) in the Philippines Higher Education Institutions (HEIs) has placed students at the centre of the educative process (CHED Handbook on Typology, OBE \& ISA, 2014; CMO 46 series 2012). OBE holds schools responsible in controlling the conditions that directly measure successful learning (Karim \& Yin, 2013; Spady, 1994). This places to schools the major role to equip all students with the necessary skills and competencies for them to be called successful learners. Hence, all programs and activities conducted in the school should be constructively aligned with the needs of the students to facilitate their success in education as well as in facing the challenges beyond the school premises (Karim \& Yin, 2013). Moreover, student needs change over time thus student services should be continually enhanced. Consistent to Maslow's principle, students can only develop their competencies if their deficiency needs are met (Huitt, 2007). Hence, if their needs are not addressed, it might hinder them from demonstrating an exceptional academic performance (Ramsey, 2000; Huitt, 2007).

A number of college students commonly have problems in their academic undertakings (Aspiras and Aspiras, 2014; Febrilia, Warokka, \& Abdullah, 2011). In the context of Philippines HEIs situated in remote areas of a province, it is not uncommon to see college students who do not take their studies seriously, have poor class attendance, submit poor quality requirements, refuse to participate in class activities, and get low exam scores although teachers believe they can perform better. The Office of the Student Affairs and Services (OSAS) of the institutions hold various student programs/services such as orientation programs, leadership training seminars, guidance and counselling, recognition of organizations, socio-cultural activities, sports competitions, student publications, scholarships, library services, and the like. These programs are intended to enhance and develop the students holistically. However, the recipients of some of these programs like the sociocultural, publications, and sports, are selected mostly among privileged students who can meet a certain criteria and/or quota. Thereby, not all the students are able to join the programs. Most especially, some of the offered 
programs may not directly address the needs and problems of certain students, and hence, may not effectively facilitate them for a better academic performance as they are crafted without any student needs research analysis. To address the students' issues, programs must be formulated based on the current needs of the students which are reflected by their common problems. The campus OSAS should deliver these kinds of programs to address the students' needs that contend their academic breakthroughs.

The current study conducted a needs-assessment among the students to identify the challenges (problems) they are faced with, and to facilitate the formulation of future student service goals or programs. The study gauges the impact of their problems on their academic performance to offer a needs-driven student programs. This study is premised on the fact that students' academic performance may not only be predicted by their cognitive ability (Petrides, Chamorro-Premuzic, Frederickson and Furnham, 2005) but also their problems in various aspects including academics (Lin, Pan, \& Ching, 2015), family (Bahar \& Nasirin, 2017; Wanjiku, 2010; Uwaifo, 2014; Omoruyi, 2014; Obeta, 2014), financial (Lacour \& Tissington, 2011; Alcuizar, 2016; Akessa \& Dhufera, 2015; Considine \& Zappala, 2002), social (Comedis, 2014; Furrer \& Skinner, 2003; Eleby, 2009), emotional (Ahmad-Gul, 2015; Chamundeswari, 2013; Malik \& Shahid, 2016), personal (Adeyemi \& Adeyemi, 2014; Yahaya, Ee, Bachock, Yahaya, Boon, Hashim, \& Lee, 2012), and spiritual (Idler, 2008; Wood \& Hilton, 2012; Kalyanasundaram \& Balasubramanian, 2014).

The said problems are herein operationally defined. Academic problems are the concerns of the students on their interest and motivation to study, learning skills and environment, as well as, their teachers' teaching strategies and teacher-student interactions. Family problems refer to contemporary conflicts, disruptions and/or crises within the family of the students, and between the student and family members. Financial problems refer to students' socio-economic status that reflects incapability to pay for school fees and other academic requirements.

Social problems are the challenges on the students' interpersonal relationship for friendship, family, social organizations and romantic attachments. Emotional problems are the concerns of the students on affections, depression and expressing their emotions. Personal problems refer to issues on self- efficacy and selfconcept that can be associated with academic performance; while spiritual problems reflect the needs of the students for religious expressions and spiritual practices that influence lives.

\section{RESEARCH OBJECTIVES}

The study aims mainly to determine the students' problems in various dimensions; namely, academic, family, financial, social, personal, emotional, and spiritual; to assess the impact of these problems on their academic performance in order to design needs-driven student programs.

\section{METHODOLOGY}

\section{Research design}

A descriptive survey and correlational design of research was utilized in the study. The former was used to determine the needs and problems of the students while the latter was utilized to assess the impact of their problems on their academic performance.

\section{Participants}

The profile of the 350 college student- respondents is shown in Table 1.

Table 1. Frequency Distribution of the Respondents as to Gender.

\begin{tabular}{llcc}
\hline \multicolumn{2}{c}{ Profiles } & $F$ & $\%$ \\
\hline Gender & & 221 & \\
& Female & 129 & 63.1 \\
& Male & & 36.9 \\
\hline Course Program & & \\
& *DAT-BAT & 164 & 46.9 \\
& *BSHRM & 125 & 35.7 \\
& *BSE & 61 & 17.4 \\
\hline Age & & & \\
& $16-18$ & 154 & 44.00 \\
& $19-21$ & 159 & 45.40
\end{tabular}


*DAT-BAT- Diploma in Agricultural Technology-Bachelor of Agricultural Technology

*BSHRM-Bachelor of Science in Hotel and Restaurant Management

*BSE-Bachelor of Secondary Education

\section{Instrumentation}

A scale was developed by considering literature findings on the dimensions of students' problems related to their academic performance. The researchers identified seven dimensions; namely, academic, family, financial, social, personal, emotional, and spiritual. The researchers formulated fifteen items for each factor which would be rated using the following arbitrary scales: 0 - Not at all; 1 - Very Little Extent; 2 - Little Extent; 3 Moderate Extent; 4 - Large Extent; or 5 - Very Large Extent. The content validity of the instrument was established by asking three knowledgeable individuals in the research area. Then during the first semester of school year 2017-2018, they piloted the scales to a set of thirty students to assess the understandability and clarity of the statements and whether the instrument is reliable. The reliability of the scale during the pilot testing was established using Cronbach alpha whose resulting coefficients are shown in Table 2. No items were deleted since the analysis ("items if item is deleted" analysis) shows that the Cronbach alpha coefficients were the maximum.

Table 2. Reliability of the Instrument.

\begin{tabular}{lc}
\hline \multicolumn{1}{c}{ Scales } & Cronbach Alpha \\
\hline Academic Needs/Problems & .959 \\
Family Needs/Problems & .959 \\
Financial Needs/Problems & .937 \\
Social Needs/Problems & .835 \\
Personal Needs/Problems & .835 \\
Emotional & .931 \\
Spiritual & .896 \\
\hline \multicolumn{1}{c}{ Overall } & .947 \\
\hline
\end{tabular}

\section{Data gathering}

A request letter containing the intent to conduct the study, the purpose of the research, the nature of participation of the target respondents, the data to be gathered and the confidentiality and anonymity of the data was prepared. Upon consent of the authorities and the target respondents, the instrument was administered to determine the respondents' current needs in the seven dimensions of needs/problems; namely, academic, family, financial, social, personal, emotional, and spiritual. The General Weighted Average (GWA) of the students was gathered from the registrar's office which was treated as their academic performance.

\section{Data analysis}

Students' needs and problems are only those scale items which were labeled by the students with moderate extent, large extent, and very large extent. Thus, rather than using Mean, the researchers use frequency count and percent to determine the number of respondents who have needs or problems. Mean in this case might not reflect the students' needs and problems if there are a number of students who do not experience a particular problem item in the scale. Correlation analysis using Pearson-r was used to gauge the relationship of students' problems and their academic performance. Linear regression analysis was used to determine how well the students' problems predict their academic performance.

\section{FINDINGS AND DISCUSSIONS}

As shown in Table 3, the academic problems of most students include distracted attention from noisy classmates during class discussion (66\%), poor English speaking skills (40\%), difficulty in expressing their thoughts and ideas $(34 \%)$, poor study habits (33\%), and feeling intimidated to recite or participate in group activities due to unfriendly classmates $(30 \%)$. 
Table 3. Students' Academic Needs/Problems.

\begin{tabular}{|c|c|c|c|c|c|}
\hline \multirow[b]{2}{*}{ Academic Problems } & \multicolumn{3}{|c|}{ Extent } & \multirow[b]{2}{*}{$f$} & \multirow[b]{2}{*}{$\%$} \\
\hline & Moderate & Great & Very Great & & \\
\hline 1. I have poor study habits. & 91 & 20 & 4 & 115 & 33 \\
\hline $\begin{array}{l}\text { 2. I have noisy classmates which distract my } \\
\text { attention during class discussion. }\end{array}$ & 81 & 79 & 70 & 230 & 66 \\
\hline $\begin{array}{l}\text { 3. I have unfriendly classmates who make me feel } \\
\text { intimidated to recite or participate in group } \\
\text { activities. }\end{array}$ & 67 & 26 & 11 & 104 & 30 \\
\hline $\begin{array}{l}\text { 4. Some of my teachers are inefficient and ineffective } \\
\text { in teaching. }\end{array}$ & 32 & 18 & 7 & 57 & 16 \\
\hline $\begin{array}{l}\text { 5. Some of my teachers are unapproachable and } \\
\text { inconsiderate. }\end{array}$ & 29 & 12 & 5 & 46 & 13 \\
\hline 6. I felt embarrassed in our class. & 33 & 16 & 5 & 54 & 15 \\
\hline $\begin{array}{l}\text { 7. I have difficulty in expressing my thoughts and } \\
\text { ideas. }\end{array}$ & 78 & 32 & 8 & 118 & 34 \\
\hline 8. I am poor in speaking English. & 85 & 47 & 9 & 141 & 40 \\
\hline 9. I lack focus and cannot concentrate in my studies. & 57 & 15 & 3 & 75 & 21 \\
\hline 10. I lack interest and motivation to finish my studies. & 22 & 9 & 12 & 43 & 12 \\
\hline 11. I often get absent/ tardy from my classes. & 22 & 8 & 2 & 32 & 9 \\
\hline 12. I have poor academic performance. & 48 & 4 & 1 & 53 & 15 \\
\hline 13. I have very strict teachers. & 46 & 20 & 7 & 73 & 21 \\
\hline 14. I have poor reading ability. & 21 & 10 & 3 & 34 & 10 \\
\hline 15. I find it hard to understand my lessons. & 40 & 11 & 1 & 52 & 15 \\
\hline Average & & & & 82 & 23 \\
\hline
\end{tabular}

Table 4 shows that very strict parents (17\%), father with many vices (13\%), not living with family (12\%), lack of moral support from parents $(11 \%)$ and too much work at home $(11 \%)$ are among the family problems indicated by few students.

Table 4. Students' Family Needs/Problems.

\begin{tabular}{|c|c|c|c|c|c|}
\hline \multirow[b]{2}{*}{ Family Problems } & \multicolumn{3}{|c|}{ Extent } & \multirow[b]{2}{*}{$f$} & \multirow[b]{2}{*}{$\%$} \\
\hline & Moderate & Great & $\begin{array}{l}\text { Very } \\
\text { Great }\end{array}$ & & \\
\hline 1. My parents are separated. & 5 & 4 & 19 & 28 & 8 \\
\hline $\begin{array}{l}\text { 2. I am bothered with the frequent quarrels of my } \\
\text { parents. }\end{array}$ & 11 & 10 & 7 & 28 & 8 \\
\hline 3. We do not have a good relationship in the family. & 14 & 10 & 9 & 33 & 9 \\
\hline 4. My parents are very strict. & 32 & 11 & 16 & 59 & 17 \\
\hline 5. My father has many vices. & 23 & 10 & 12 & 45 & 13 \\
\hline $\begin{array}{l}\text { 6. My father/mother is involved to another } \\
\text { woman/man. }\end{array}$ & 6 & 3 & 19 & 28 & 8 \\
\hline 7. I lack moral support from my parents. & 16 & 8 & 15 & 39 & 11 \\
\hline 8. I am bothered with my mother's nagging. & 15 & 3 & 2 & 20 & 6 \\
\hline 9. My mother has some vices. & 9 & 2 & 9 & 20 & 6 \\
\hline 10. I feel that my parents do not love me. & 7 & 5 & 6 & 18 & 5 \\
\hline 11. I feel that my parents play favourites. & 7 & 5 & 2 & 14 & 4 \\
\hline $\begin{array}{l}\text { 12. I have problems with taking care of my brothers } \\
\text { and } \\
\text { sisters. }\end{array}$ & 18 & 7 & 5 & 30 & 9 \\
\hline 13. There is too much work at home. & 27 & 12 & 1 & 40 & 11 \\
\hline 14. I feel that my brothers and sisters do not love me. & 9 & 5 & 4 & 18 & 5 \\
\hline 15. I am not living with my family. & 11 & 6 & 25 & 42 & 12 \\
\hline Average & & & & 31 & 9 \\
\hline
\end{tabular}

The greatest number of students having financial problems indicated that they have no other relatives to support/help in their financial needs (28\%), and they lack money to provide their everyday needs (25\%) and for their contributions $(27 \%)$. 
Table 5. Students' Financial Needs/Problems.

\begin{tabular}{|c|c|c|c|c|c|}
\hline \multirow[b]{2}{*}{ Financial Problems } & \multicolumn{3}{|c|}{ Extent } & \multirow[b]{2}{*}{$f$} & \multirow[b]{2}{*}{$\%$} \\
\hline & Moderate & Great & Very Great & & \\
\hline 1. We lack money to provide our everyday needs. & 54 & 23 & 9 & 86 & 25 \\
\hline 2. I am bothered with the financial debts of my parents. & 25 & 25 & 17 & 67 & 19 \\
\hline 3. We have no other relatives to support/help us financially. & 49 & 27 & 21 & 97 & 28 \\
\hline $\begin{array}{l}\text { 4. My parents do not have an extra income to suffice the } \\
\text { expenses in the family. }\end{array}$ & 28 & 13 & 15 & 56 & 16 \\
\hline 5. My parents have no occupations. & 45 & 19 & 15 & 79 & 23 \\
\hline 6. I lack money for school requirements. & 45 & 22 & 10 & 77 & 22 \\
\hline 7. I lack money for contributions. & 41 & 25 & 27 & 93 & 27 \\
\hline $\begin{array}{l}\text { 8. I feel that I need to work to be able to send myself to } \\
\text { school. }\end{array}$ & 18 & 3 & 7 & 28 & 8 \\
\hline $\begin{array}{l}\text { 9. I have frequent absences in my classes because I do not } \\
\text { have money for transportation. }\end{array}$ & 34 & 11 & 10 & 55 & 16 \\
\hline 10. I have a burden in paying my school fees. & 35 & 18 & 28 & 81 & 23 \\
\hline $\begin{array}{l}\text { 11. I am afraid I will not be able to finish my studies due to } \\
\text { financial problem. }\end{array}$ & 30 & 7 & 7 & 44 & 13 \\
\hline 12. My parents have frequent quarrels about money. & 11 & 10 & 15 & 36 & 10 \\
\hline 13. My parents do not support me financially in my studies. & 29 & 12 & 12 & 53 & 15 \\
\hline 14. My studies in college were interrupted because of & 22 & 11 & 19 & 52 & 15 \\
\hline financial problem. & & & & & \\
\hline \multirow[t]{2}{*}{$\begin{array}{l}\text { 15. My other siblings are not able to continue their studies } \\
\text { because of financial difficulty. }\end{array}$} & 10 & 1 & 4 & 15 & 4 \\
\hline & & & & 61 & 18 \\
\hline
\end{tabular}

Some students specified that they want to have a girlfriend/boyfriend (40\%); they have friends with bad influences $(23 \%)$; they have difficulty in dealing with people (17\%); and they want to know how a good relationship works (17\%). See Table 6.

Table 6. Students' Social Needs/Problems.

\begin{tabular}{lcccccc}
\hline \multicolumn{1}{c}{ Social Needs/Problems } & Extent & & & \\
\cline { 2 - 3 } & Mreat & Very Great & $f$ & $\%$ \\
\hline 1. I do not have close friends. & 19 & 8 & 6 & 33 & 9 \\
2. I have an anti-social behaviour. & 31 & 4 & 5 & 40 & 11 \\
3. My friends do not understand me. & 39 & 11 & 6 & 56 & 16 \\
4. I feel out of place to some social gatherings. & 16 & 6 & 9 & 31 & 9 \\
5. My friends are bad influences. & 32 & 18 & 29 & 79 & 23 \\
6. I don't know how a good relationship works. & 45 & 7 & 8 & 60 & 17 \\
7. I have difficulty in dealing with other people. & 32 & 13 & 13 & 58 & 17 \\
8. I am being criticized by others. & 13 & 1 & 5 & 19 & 5 \\
9. I always get into trouble. & 24 & 8 & 6 & 38 & 11 \\
10. I do not want to engage in boy-girl relationship. & 18 & 5 & 14 & 37 & 11 \\
11. My boyfriend/girlfriend is not faithful to me. & 18 & 4 & 12 & 34 & 10 \\
12. I am not happy with my boyfriend/girlfriend. & 22 & 11 & 16 & 49 & 14 \\
13. I don't have a boyfriend/girlfriend. & 20 & 25 & 95 & 140 & 40 \\
14. I don't have a true friend. & 22 & 8 & 14 & 44 & 13 \\
15. My best friend betrayed me. & 8 & 1 & 2 & 11 & 3 \\
\hline \multicolumn{2}{c}{ Average } \\
\hline
\end{tabular}

Table 7 shows that there are many students who feel unsure of themselves (42\%), worried about their future $(34 \%)$, feel immature $(30 \%)$, and have attitude problems $(25 \%)$.

Table 7. Students' Personal Needs/Problems.

\begin{tabular}{lccccc}
\hline \multirow{2}{*}{ Needs/Problems } & \multicolumn{3}{c}{ Extent } & & \\
\cline { 2 - 5 } & Moderate & Great & Very Great & $f$ & \\
\hline 1. I do not have a clear purpose about my life. & 39 & 23 & 12 & 74 & 21 \\
2. I do not have self-confidence. & 17 & 10 & 7 & 34 & 10 \\
3. I am immature. & 45 & 21 & 39 & 105 & 30
\end{tabular}




\begin{tabular}{lccccc} 
4. I am worried about my future. & 54 & 28 & 36 & 118 & 34 \\
5. I have many problems. & 23 & 10 & 6 & 39 & 11 \\
6. I feel nobody loves me. & 33 & 14 & 13 & 60 & 17 \\
7. I find it difficult to handle all my problems. & 14 & 6 & 2 & 22 & 6 \\
8. I have plans to commit suicide. & 14 & 9 & 5 & 28 & 8 \\
9. I hate myself. & 26 & 8 & 7 & 41 & 12 \\
10. I cannot understand myself. & 26 & 10 & 3 & 39 & 11 \\
11. I think that I am not attractive. & 21 & 8 & 9 & 38 & 11 \\
12. I feel unsure of myself. & 35 & 16 & 95 & 146 & 42 \\
13. I want to become a better person. & 46 & 16 & 9 & 71 & 20 \\
14. I have attitude problems. & 48 & 16 & 23 & 87 & 25 \\
15. It is difficult for me to make decisions. & 9 & 3 & 0 & 12 & 3 \\
\hline \multicolumn{1}{c}{ Average } & & & & 61 & 17 \\
\hline
\end{tabular}

A large number of the respondents lack affection from their family, feel rejected and depressed most of the time, and face an emotional problem of not expressing their anger to someone (see Table 8).

Table 8. Students' Emotional Needs/Problems.

\begin{tabular}{lccccc}
\hline \multicolumn{1}{c}{ Emotional Problems } & \multicolumn{3}{c}{ Extent } & & \\
\cline { 2 - 4 } & Moderate & Great & Very Great & $f$ & $\%$ \\
\hline 1. I feel lonely most of the time. & 33 & 14 & 16 & 63 & 18 \\
2. I feel depressed most of the time. & 44 & 24 & 22 & 90 & 26 \\
3. I cannot express my anger to someone. & 36 & 24 & 24 & 84 & 24 \\
4. I am not expressive of my emotions. & 19 & 6 & 11 & 36 & 10 \\
5. I lack affection from my family. & 47 & 27 & 25 & 99 & 28 \\
6. I am very sensitive or easily get hurt. & 21 & 2 & 18 & 41 & 12 \\
7. I am broken hearted. & 31 & 12 & 16 & 59 & 17 \\
8. I am hot-tempered. & 11 & 21 & 2 & 34 & 10 \\
9. I am easily get embarrassed. & 33 & 17 & 18 & 68 & 19 \\
10. I am too easily discouraged. & 25 & 20 & 16 & 61 & 17 \\
11. I feel rejected. & 28 & 20 & 44 & 92 & 26 \\
12. I need someone to love me. & 30 & 16 & 8 & 54 & 15 \\
13. I often feel insecure to other ladies/guys. & 20 & 9 & 10 & 39 & 11 \\
14. I feel emptiness in my life. & 32 & 14 & 19 & 65 & 19 \\
15. It is hard for me to forgive. & 7 & 4 & 2 & 13 & 4 \\
\hline \multicolumn{1}{c}{ Average } & & & 60 & 17 \\
\hline
\end{tabular}

There are many students who claimed that they have a poor spiritual life and never read the bible (see Table 9).

Table 9. Students' Spiritual Needs/Problems.

\begin{tabular}{|c|c|c|c|c|c|c|}
\hline \multirow[b]{2}{*}{ Needs/Problems } & \multicolumn{3}{|c|}{ Extent } & & \multirow[b]{2}{*}{$f$} & \multirow[b]{2}{*}{$\%$} \\
\hline & Moderate & \multirow{2}{*}{$\frac{\text { Great }}{7}$} & \multicolumn{2}{|c|}{ Very Great } & & \\
\hline $\begin{array}{l}\text { 1. I feel that it is useless to dream because God plays } \\
\text { favourites. }\end{array}$ & 14 & & 4 & & 25 & 7 \\
\hline 2. I do not know how to pray well. & 12 & 5 & 4 & & 21 & 6 \\
\hline $\begin{array}{l}\text { 3. I do not like to participate/ attend any spiritual } \\
\text { growth activity. }\end{array}$ & 6 & 10 & 8 & & 24 & 7 \\
\hline 4. I am confused about God. & 11 & 7 & 5 & & 23 & 7 \\
\hline 5. I am confused about my religion. & 29 & 11 & 25 & & 65 & 19 \\
\hline $\begin{array}{l}\text { 6. I like to attend Holy Mass every Sunday but I am } \\
\text { busy. }\end{array}$ & 16 & 7 & 8 & & 31 & 9 \\
\hline 7. My family is not spiritually-oriented. & 19 & 3 & 17 & & 39 & 11 \\
\hline $\begin{array}{l}\text { 8. I like to attend spiritual activities but there is no } \\
\text { program available in the campus. }\end{array}$ & 23 & 8 & 26 & & 57 & 16 \\
\hline $\begin{array}{l}\text { 9. I like to join/participate any spiritual activity in the } \\
\text { school if this will be provided. }\end{array}$ & 11 & 10 & 9 & 30 & & 9 \\
\hline 10. I lack faith in God. & 23 & 6 & 12 & 41 & & 12 \\
\hline 11. I never read the bible. & 30 & 12 & 83 & 125 & & 36 \\
\hline & 29 & 12 & 8 & 49 & & 14 \\
\hline 12. I need to know more about God. & & & & & & \\
\hline 13. I have a poor spiritual life. & 58 & 36 & 59 & 153 & & 44 \\
\hline 14. I have so many sins. & 24 & 8 & 13 & 45 & & 13 \\
\hline 15. I think that God does not easily forgive sins. & 7 & 4 & 3 & 14 & & 4 \\
\hline
\end{tabular}


As

As

in Table 10, one in every 5 students have academic problems; 1 in every 6 students have financial, personal, and emotional needs/problems; 1 in every 7 have social and spiritual needs/problems; while only 1 in every 11 students have family problems. The results show that most students experience more academic issues than other dimensions of needs. This finding, however, can be associated with the fact that they spent most of their time in the academe.

Table 10. Summary of Cases of the Students' Needs and Problems.

\begin{tabular}{llccc}
\hline & Dimensions & $f$ & $\%$ & Rank \\
\hline 1. & Academic & 82 & 23.43 & 1 \\
2. & Family & 31 & 8.86 & 7 \\
3. & Financial & 61 & 17.43 & 2.5 \\
4. & Social & 49 & 14.00 & 5.5 \\
5. & Personal & 61 & 17.43 & 2.5 \\
6. & Emotional & 60 & 17.14 & 4 \\
7. & Spiritual & 49 & 14.00 & 5.5 \\
\hline
\end{tabular}

Table 11 supports that the students' needs and problems in academics, family, financial, social, personal, emotional, and spiritual adversely impact their academic performance. Financial needs and spiritual needs are both largely correlated with academic performance sharing a variance of $35.76 \%$ and $27.04 \%$, respectively. The other five dimensions of needs are moderately associated with academic performance, having explanatory powers ranging from $18.49 \%$ to $20.79 \%$. Their needs, in general, predict a variance of $25.70 \%$ in their academic performance.

Table 11. Impact of Students' Needs and Problems on their Academic Performance.

\begin{tabular}{|c|c|c|c|}
\hline Factors of Academic Performance & $r$ & $p$ & $R^{2}(\%)$ \\
\hline Academic Needs/Problems & -0.456 & .03 & 20.79 \\
\hline Family Needs/Problems & -0.430 & .05 & 18.49 \\
\hline Financial Needs/Problems & -0.598 & .00 & 35.76 \\
\hline Social Needs/Problems & -0.495 & .01 & 24.50 \\
\hline Personal Needs/Problems & -0.456 & .03 & 20.79 \\
\hline Emotional Needs/Problems & -0.450 & .04 & 20.25 \\
\hline Spiritual Needs/Problems & -0.520 & .01 & 27.04 \\
\hline Overall & -0.507 & .01 & 25.70 \\
\hline
\end{tabular}

Note. Criterion for each correlation is Academic Performanc

Based on the gathered data above, student development programs were crafted (Table 12) which will be implemented accordingly by the OSAS unit of the campus.

Table 12. Student Programs.

\begin{tabular}{|c|c|c|}
\hline $\begin{array}{l}\text { Programs/ } \\
\text { Strategies }\end{array}$ & Participants & Desired Outcomes \\
\hline $\begin{array}{l}\text { Communication } \\
\text { Skills } \\
\text { Development }\end{array}$ & Students & $\begin{array}{l}\text { 1. Increase dramatically their ability to tune into others } \\
\text { in order to communicate effectively. } \\
\text { 2. Use the language in realistic situations in class to } \\
\text { communicate openly with their peers and teachers. }\end{array}$ \\
\hline $\begin{array}{l}\text { Developing self - } \\
\text { esteem and } \\
\text { Projecting } \\
\text { Credibility }\end{array}$ & Students & $\begin{array}{l}\text { 1. Cultivate personal presence } \\
\text { 2. Recognize/prevent the "tells" of nervousness and } \\
\text { intimidation } \\
\text { 3. Strike a balance between authority and } \\
\text { approachability } \\
\text { 4. Demonstrate composure under pressure } \\
\text { 5. Avoid unintentional behaviours that may lower status }\end{array}$ \\
\hline
\end{tabular}




\begin{tabular}{|c|c|c|}
\hline $\begin{array}{l}\text { Developing Peer } \\
\text { Relationship }\end{array}$ & Students & $\begin{array}{l}\text { 1. Develop communication skills towards peers } \\
\text { 2. Enhance assertiveness in dealing conflicts } \\
\text { 3. Develop good manners inside the classroom }\end{array}$ \\
\hline Parenting & $\begin{array}{l}\text { Students and their } \\
\text { Parents }\end{array}$ & $\begin{array}{l}\text { 1. Develop good interactions between parents and } \\
\text { students } \\
\text { 2. Break the barriers of generation gap of values } \\
\text { 3. Increase understanding of better time management in } \\
\text { doing household chores }\end{array}$ \\
\hline $\begin{array}{l}\text { Strengthening } \\
\text { information } \\
\text { dissemination } \\
\text { about } \\
\text { Scholarship and } \\
\text { Grants }\end{array}$ & Students & $\begin{array}{l}\text { 1. Cope with financial problems } \\
\text { 2. Be informed about the existing scholarship and grants } \\
\text { inside and outside the school premise } \\
\text { 3. Be encouraged to apply in offered scholarship and } \\
\text { grants }\end{array}$ \\
\hline $\begin{array}{l}\text { Leadership } \\
\text { Training }\end{array}$ & Students & $\begin{array}{l}\text { 1. Implement practical steps for self-improvement } \\
\text { 2. Master the fundamentals of leadership } \\
\text { 3. Build confidence } \\
\text { 4. Set long-term/visionary goals } \\
\text { 5. Demonstrate understanding of how leadership styles } \\
\text { affect team members and how to adjust those styles } \\
\text { to gain commitment } \\
\text { 6. Build trust and reduce resistance to change } \\
\text { 7. Sharpen communication and people skills to } \\
\text { energize your entire team for higher productivity and } \\
\text { greater success }\end{array}$ \\
\hline $\begin{array}{l}\text { True love } \\
\text { waits.... Never } \\
\text { late symposium }\end{array}$ & Students & $\begin{array}{l}\text { 1. Have a plan of priorities in life } \\
\text { 2. Demonstrate understanding of the issues of boy and } \\
\text { girl relationship } \\
\text { 3. Be aware of morality of boy-girl relationship and } \\
\text { evidence of early pregnancy }\end{array}$ \\
\hline $\begin{array}{l}\text { Gender } \\
\text { Sensitivity and } \\
\text { Self - Awareness } \\
\text { Program }\end{array}$ & Students & $\begin{array}{l}\text { 1. Discover how their perception of gender differences } \\
\text { originated } \\
\text { 2. Identify the differences between sex and gender } \\
\text { 3. Distinguish what gender discriminatory attitudes and } \\
\text { values are } \\
\text { 4. Identify the surrounding organization when men and } \\
\text { women learn, experience, and practice gender } \\
\text { discrimination. }\end{array}$ \\
\hline $\begin{array}{l}\text { Stress } \\
\text { Management } \\
\text { Program }\end{array}$ & $\begin{array}{c}\text { Students, Parents, } \\
\text { Employees }\end{array}$ & $\begin{array}{l}\text { 1. Boost resilience in facing life adversities } \\
\text { 2. Develop better support system from family, friends } \\
\text { and school setting } \\
\text { 3. Impart practical ways in coping }\end{array}$ \\
\hline $\begin{array}{l}\text { Peer Helper } \\
\text { Program }\end{array}$ & Students & $\begin{array}{l}\text { 1. Provide a safe space and learning environment for } \\
\text { young people without fear of judgment, } \\
\text { misunderstanding, harassment or abuse. } \\
\text { 2. Increase social connectedness and create a sense of } \\
\text { belongingness within supportive peer networks. } \\
\text { Provide positive role models, positive peer } \\
\text { influences and opportunities which help young } \\
\text { people to develop a positive self-concept, self- } \\
\text { acceptance and high self-esteem. } \\
\text { Prevent the onset or further development of mental } \\
\text { health problems including depression, anxiety, self- } \\
\text { harm and suicidal ideation. } \\
\text { Increase confidence and develop and enhance } \\
\text { communication and social skills. } \\
\text { Empower young people to build personal resilience } \\
\text { and improved help-seeking behavior through } \\
\text { increased knowledge of available support, reduced } \\
\text { stigma associated with mental health difficulties and } \\
\text { help-seeking, the development of positive coping } \\
\text { strategies and the development of skills needed to } \\
\text { access help. } \\
\text { Foster future thinking and optimism and to widen } \\
\text { young people's understanding and beliefs of the } \\
\text { opportunities available to them. }\end{array}$ \\
\hline
\end{tabular}




\begin{tabular}{|c|c|c|}
\hline $\begin{array}{l}\text { Formulation of } \quad \text { Students } \\
\text { Religious } \\
\text { Organizations }\end{array}$ & $\begin{array}{l}3 . \\
4 .\end{array}$ & $\begin{array}{l}\text { Form religious organizations according to their } \\
\text { respective religious sect } \\
\text { 2. Empower their religious beliefs } \\
\text { Value the importance of spiritual life as a coping } \\
\text { mechanism to stressors } \\
\text { Grow spiritually toward divine providence }\end{array}$ \\
\hline
\end{tabular}

\section{DISCUSSIONS}

This study found that the academic needs of a number of students include, but not limited to, proficient English speaking skills, focused attention during class discussion, confidence in expressing their thoughts and ideas, and good study habits. Some students need having parents with no vices who support them morally in their studies. A number of students also specified that they need financial support for their studies and everyday needs. Some also specified social needs to have a girlfriend/boyfriend, good friends, and effective social skills. Many students lack intrapersonal skills, worried about their future, feel immature, and have attitude problems. A large number of the respondents lack affection from their family, feel rejected and depressed most of the time, and face an emotional problem of not expressing their anger to someone. Similarly, many students admitted that they have a poor spiritual life and never read the bible. The study found that all these needs and problems in academics, financial, family, personal, social, emotional and spiritual aspects are all significant predictors of academic performance.

The study confirms that financial problems significantly explained the greatest variance $(35.76 \%)$ in academic performance which suggests that as compared to the other students' needs/problems this factor has the largest (adverse) effect to students' scholastic performance. This supports the findings of previous research although they might have used different models of financial needs. Lacour and Tissington (2011), for instance, reported that students' achievement is directly influenced by income, source of income, and their mother's educational level. Alcuizar (2016) also found that nutrition and living condition are the best significant predictors of students' low performance. Considine and Zappala (2002) revealed that parental educational attainment as reflection of socio-economic status is a predictor of students' academic performance; while Akessa and Dhufera (2015) confirmed that parents' educational level and economic status are highly correlated to the students' academic achievement. This implies that the students really need a responsive scholarship unit and program. Wide dissemination of existing scholarship grants inside and outside the campus is needed to encourage students to apply. Moreover, student assistantship program among schools should also be available to support students' financial needs.

Spiritual problems have the second largest significant impact on the students' academic performance. According to Idler (2008), the choice one makes based on spiritual beliefs and values directly relate to the creation of certain lifestyle habits, such as diet, alcohol use, and sexual practices; hence, good spiritual beliefs can contribute to a good study habit and well-balanced academic performance. Wood and Hilton (2012) elaborate that spirituality is a positive factor affecting academic success as it serves as a confidant and inspiration for excellence, provides life purpose and ability to overcome barriers, and reduces relational distractions. Kalyanasundaram and Balasubramanian (2014), in an experimental investigation, confirmed that spirituality intelligence is significantly related to students' performance. Therefore, religious organizations in schools should actively organize religious activities that emphasize to students the significance of spiritual life, in order to motivate them to learn, cope with stress, and further understand life endeavours.

Social problems as one of the major complications of students in a university (Lin, Pan, \& Ching, 2015) also share a variance of $24.50 \%$ with academic performance. Furrer and Skinner (2003) assert that students with higher sense of relatedness also have greater emotional and behavioural engagement in school, thus, have greater opportunities for educational success. Comedis (2014) affirm, on the other hand, that academic performance can be associated with self-control and overall social skills; while Eleby (2009) posits that social skills can enhance students' ability to stay in school and enhance peer and teach bonding which can ultimately increase academic performance. To address the social needs/problems of the students, the student affairs and services unit may spearhead the conduct of trainings, workshops, activities and counselling on developing peer relationship to effectively guide students in dealing conflicts on interpersonal relationships and create plans about priorities in life.

Academic problems predict $20.79 \%$ of the students' academic performance. This predictive power supports that academic issues really have large negative effect on students' performance (Hashem, Al Khawaja, Edhah, Hashmi and Al Akill 2014). Some academic-related complications in a university, as indicated by previous research, include lessons, exams, learning difficulties (Lin, Pan and Ching, 2015), and internal classroom factors (Principe, 2005). Therefore, academic councils should give emphasis on the pedagogies and assessments that adapt to these academic problems and needs of the students. Teaching-learning activities and 
assessments should be prepared and used to facilitate students to achieve desired outcomes. Their success in prior learning experiences and assessments can be used to motivate them to pursue and succeed further in education (Spady, 1994).

Moreover, personal needs and problems particularly on self-efficacy or self-concept issues are also a significant factor of academic performance having an explanatory power of $20.79 \%$ to the latter. This finding negates that of Adeyemi and Adeyemi (2014) that self-concept is not a significant predictor of academic achievement. Nonetheless, it supports Yahaya, Ee, Bachock, Yahaya, Boom, Hashim, and Lee (2012), in their study, that self-awareness can be associated with academic performance. With this, effective orientations on school policies and processes especially to freshmen students should also be given emphasis for them to adjust positively to college life. The student affairs and services unit of the school may consider seminars and symposiums related to cultivating self-esteem and credibility that will help in improving the skills of the students in learning.

The emotional needs and problems explain a variance of $20.25 \%$ of the students' academic performance. Chamundeswari (2013), Mishra (2012), Nwadinigwe and Azuka-Obieke (2012), and Yahaya et al. (2012) reveal that students' emotional intelligence is significantly related to their academic performance. Ahmad-Gul (2015) asserts that socio-emotional adjustment is directly related to and has significant impact on the students' academic achievement. Hashempour and Mehrad (2014) posit that ones' anxiety has a negative impact on working memory causing the emotional intelligence to create difficulties in learning. Malik and Shahid (2016) also found that emotional intelligence and academic performance are significantly correlated. On the other hand, Febrilia, Warokka, and Adbullah (2011) assert that having positive mood cannot affect learning but having negative mood can negatively influence learning. Students have their own unique emotional needs and it should not be ignored if students are expected to maximize their potential in learning. Therefore, stakeholders of the school should be oriented in coping up with learning adversaries as well as practical ways to support the learning system and school environment.

Further, although family needs and problems have the least impact on students' academic performance (18.49\%), it still yields to significant explanatory power. This proves that family conflicts affect students' cognitive and affective growth (Wanjiku, 2010). Research has shown that students with two parents in their respective families have better academic performance than those with only one parent (Uwaifo, 2014) as academic performance associates with broken homes (Omoruyi, 2014). Research explains this phenomenon as broken marriage contributes a lot to students' psychological problems, delinquent behaviors, and poor academic performance (Bubelwa, 2014), while parents' involvement, on the other hand, contributes to better academic performance of their children (Rafiq, Fatima, Sohail, Saleem and Khan, 2013; Kamuti, 2015). Thereby, parents' provision of adequate materials to their children, parental teaching, and parental supervision of their work are salient factors in enhancing students' academic performance (Obeta, 2014). However, parents must value first the importance of parental support and must believe that their children can achieve better in education (Bahar \& Nasirin, 2017). Hence, the conduct of parenting seminar programs must be considered as well as involving parents to school activities for them to value more their roles to students and understand generation gaps; and for the students to acknowledge time management in school and at home.

\section{CONCLUSIONS AND RECOMMENDATIONS}

The research proves that students face the academe while they experience challenging problems in life including in school. The student problems disclose teachers' lapses in classroom management and pedagogy, and lack of activities that support students' holistic development and effective learning habits. This explains why students may not still learn successfully despite teachers' efforts to increase academic achievement. Students' concerns are potential factors that can deteriorate scholastic performance, and hence, they must be considered in the crafting of outcomes, curricula, and assessments.

This research serves as significant feedbacks to students, teachers, and parents regarding what they should do to facilitate successful student learning. For students, the research provides them information as to what strands they should focus more to have a better scholastic performance. The research also offers them needs-driven student programs so they can have more opportunities to overcome their weaknesses and problems. For teachers, the research informs instruction especially about what dimensions of their students' learning should be given attention to and provided with learning experiences in order to expect better learning outcomes. The research gives them understanding of their learners' persona hence, enlightens and broadens their perspectives about teaching and learning. For parents, with the research, they may know to what extent they should provide assistance and opportunities for their children's education.

The study suggests the student services unit of the HEI to implement the proposed student programs. The programs are centred on addressing the basic needs of typical students. They are geared toward promoting holistic development among students as they supplement classroom instructions. The programs being outcome- 
oriented might provide the learners with necessary learning experiences and tools that can help them succeed in education and life, in general.

However, the findings of the study may only apply to the 350 respondents and other comparable students. Questionnaire method was only used to identify the problems of the students, and therefore, there is lack of investigation and explanation on the "why" and "how" of the students' problems. The research instrument was not also factor-analysed and thus, the construct of student problems was predetermined based on existing literature. Similarly, although the regression results yield statistical significance, academic performance herein is the average grades of the students taken from the registrar's office (not measured through standardized testing) and hence, might be influenced by factors other than the variables of interests.

Hence, this study recommends further quantitative research in which academic performance is measured through a normalized test, in order to validate the practicability of existing findings in this research area; a broad-based qualitative research whose aim is to understand in depth the identified specific student problems and form theoretical frameworks and models of solving student problems; and factor analytic design research to assess the factor structure of the construct (as well as the factorial validity of the instrument) and understand further the link between the variables that make up the construct.

\section{REFERENCES}

Adeyemi, A., \& Adeyemi, S. (2014). Personal factors as predictors of students' academic achievement in colleges of education in south western Nigeria. Educational Research and Reviews, 9(4), 97-109. doi: 10.5897/ERR2014.1708

Ahmad-Gul, S. B. (2015). Impact of socio-emotional adjustment on academic achievement of adolescent girls in Jammu and Kashmir. Sodha Pravaha [A Multidisciplinary Refereed Research Journal], 5(3), 21-28.

Akessa, G., \& Dhufera, A. (2015). Factors that influence students' academic performance: A case of Rift Valley University, Jimma, Ethiopia. Journal of Education and Practice, 6(22), 55-64.

Alcuizar, R. (2016). Determinants of low academic performance for pupils in upland barangays, Iligan City, Philippines. International Journal of Physical Education, Sports and Health, 3(2): 321-325

Aspiras, L., \& Aspiras, E. (2014, December 10-11). Perceived stress factors and academic performance of the sophomore IT students of QSU Cabarroguis Campus. Paper presented at International Conference on Economics, Education and Humanities, Bali, Indonesia. doi.org/10.15242/ICEHM.ED1214125

Bahar, I. A. A., \& Nasirin, S. (2017). Exploring the determinants influencing university students' high academic achievement: A high performance equation model. Journal of Research, Policy \& Practice of Teachers \& Teacher Education, 7(1), 21-35.

Bubelwa, C. (2014). Effects of broken marriage on primary school pupils' academic performance in Ilala Municipality (Unpublished doctoral dissertation). Open University of Tanzania.

Chamundeswari, S. (2013). Emotional Intelligence and Academic Achievement among Students at the Higher Secondary Level. International Journal of Academic Research in Economics and Management Sciences, 2(4), 178-187.

CHED Memorandum Order (CMO) No. 46, Series of 2012. Retrieved from http://www.aaccupqa.org.ph/images/Downloadables/NationalConference2018/Keynote\%20Speech\%20$\% 20 \mathrm{Mr} . \% 20$ Napoleon\%20B.\%20Imperial.pdf

Comedis, E. J. (2014). The role of social skills in the academic performance of De La Salle Araneta University freshmen students: Creating a culture. Paper presented at DLSU Research Congress, De La Salle University, Manila, Philippines. DLSU Research Congress.

Commission on Higher Education (2014). Handbook on Typology, Outcomes-based Education, and Institutional Sustainability Assessment. Retrieved from http://www.ched.gov.ph/wpcontent/uploads/2014/06/Handbook\%20on\%20Typology\%20Outcomes.pdf

Considine, G. \& Zappala, G. (2002). Influence of social and economic disadvantages in the academic performance of school students in Australia. Journal of Sociology, 38(1), 129-148.

Eleby, C. (2009). The impact of a student's lack of social skills on their academic skills in high school (Unpublished master's thesis). Marygrove College, Detroit, Michigan.

Febrilia, I., Warokka, A., \& Abdullah, H. (2011). University students' emotional state and academic performance: New insights of managing complex cognitive. Journal of e-Learning and Higher Education. Retrieved from: https://ibimapublishing.com/articles/JELHE/2011/879553/

Furrer, C., \& Skinner, E. (2003). Sense of relatedness as a factor in children's academic engagement and performance. Journal of Educational Psychology, 95(1), 148-162. DOI: 10.1037/0022-0663.95.1.148

Hashem, M. H., Al Khawaja, A. A., Edhah, S. O., Hashmi, U. I., Al Akill, A. (2014, April 3-5). How Do Academic Issues Affect College Students' Performance. Paper presented at ASEE 2014 Zone 1 Conference. University of Bridgeport, Bridgeport, CT, USA.

Hashempour, S., \& Mehrad, A. (2014). The effect of anxiety and emotional intelligence on students' learning process. Journal of Education \& Social Policy, 1(2), 115-122.

Huitt, W. (2007). Maslow's hierarchy of needs. Educational Psychology Interactive. Valdosta, GA: Valdosta State University.

Idler, E. (2008). The psychological and physical benefits of spiritual/religious practices. Spirituality in Higher Education Newsletter, 4(2), 1-5.

Kalyanasundaram, K. \& Balasubramanian, P. (2014). Effect of spirituality on human performance - A myth or 
Reality?.SMS: Vanarasi, 7(1), 34-42.

Kamuti, J. (2015). Influence of home environment on academic performance of students in public secondary schools in Kitui West Sub County, Kitui, County, Kenya. Retrieved from https://pdfs.semanticscholar.org/e0b1/d6f96b7f83b436fb291b870ffedbeda0b62a.pdf

Karim, N. A., \& Yin, K. Y. (2013). Outcome-based education: An approach for teaching and learning development. Journal of Research, Policy \& Practice of Teachers \& Teacher Education, 3(1), 26-35.

Lacour, M. \& Tissington, L. (2011). The effects of poverty on academic achievement. Educational Research and Reviews, 6(7), 522-527

Lin, M., Pan, C., \& Ching, G. (2015). Common problems and coping solutions of university students in Taiwan.

International Journal of Research Studies in Education, 4(1), 3-16.

Malik, S., \& Shahid, S. (2016). Effect of emotional intelligence on academic performance among business students in Pakistan. Bulletin of Education and Research, 38(1), 197-208.

Mayes, A., \& McConatha, J. (1982). Surveying Student Needs: A Means of Evaluating Student Services. The Journal of College Student Personnel, 23, 473-476.

Mishra, P. (2012). A study of the effect of emotional intelligence on academic achievement of Jaipur senior secondary students. International Journal of Education Research and Technology, 3(4), 25-28.

Nwadinigwe, I., \& Azuka-Obieke, U. (2012). The impact of emotional intelligence on academic achievement of senior secondary school students in Lagos, Nigeria. Journal of Emerging Trends in Educational Research and Policy Studies, 3(4), 395-401.

Obeta, A. (2014, July). Home environmental factors affecting students' academic performance in Abia State, Nigeria. Paper presented at International Scientific Conference: Rural Environment. Education. Personality (REEP), Latvia. Latvia University of Agriculture.

Omoruyi, I. (2014). Influence of broken homes on academic performance and personality development of the adolescents in Lagos State Metropolis. European Journal of Educational and Development Psychology, 2(2), 10-23.

Petrides, K., Chamorro-Premuzic, T., Frederickson, N., \& Furnham, A. (2005). Explaining individual differences in scholastic behaviour and achievement. British Journal of Educational Psychology, 75, 239-255.

Principe, H. (2005). Factors influencing students' academic performance in the first accounting course: A comparative study between public and private universities in Puerto Rico (Unpublished Dissertation). Argosy University/Sarasota.

Rafiq, H., Fatima, T., Sohail, M., Saleem, M., \& Khan, M. (2013). Parental involvement and academic achievement: A study on secondary school students of Lahore, Pakistan. International Journal of Humanities and Social Science, 3(8), 209-223.

Ramsey, G. L. (2000). A freshmen student needs assessment of current services provided by the student services department at the university of Wisconsin-Stout (Unpublished Research Paper). University of Wilconsin-Stout.

Spady, W. (1994). Outcomes-based education: Critical issues and answers. Arlington, VA: American Association of School Administrators. Retrieved from http://files.eric.ed.gov/fulltext/ED380910.pdf

Uwaifo, V. (2014). The effects of family structure and parenthood on the academic performance of Nigerian university students. International Journal of Guidance and Counseling, 1(1), 001-004.

Wanjiku, M. I. (2010). Impact of family conflicts on the academic performance and interpersonal relationships of pupils in public primary schools in Nakuru municipality (Unpublished Research Project Report). Egerton University.

Wood, J. L. \& Hilton, A. A. (2012). Spirituality and academic success: Perceptions of African American males in the community college. Journal of Religion \& Education, 39(1), 28-47. doi: 10.1080/15507394.2012.648576

Yahaya, A., Ee, N., Bachok, J., Yahaya, N., Boon, Y., Hashim, S., \& Lee, G. (2012). The impact of emotional intelligence element on academic achievement. Archives Des Sciences, 65(4), 2-17. 